\title{
Att känna sig obekväm men amma ändå
}

\section{Problematiska känslor och kroppar i berättelser om offentlig amning}

Jag känner att jag själv kan slappna av bättre om jag inte behöver fundera på att nu är halva bröstet framme (Anna IF mgt 2017/072)

Anna, som jag valt att kalla henne i denna artikel, berättar om varför hon brukar ha på sig speciella kläder när hon ammar offentligt. Hennes målsättning är att det ska synas så lite som möjligt när hon ammar. Detta har inte varit helt lätt. Hon har ansträngt sig för att hitta passande kläder, något hon själv upplevt som svårt då hon har en stor byst. En sjal har hon provat, men upplevt som något som drar uppmärksamheten till sig ännu mer då bebisen gärna vill riva i den. Trots dessa svårigheter är det något hon gör, eftersom det känns bättre. Hon kan slappna av utan att behöva "fundera".

Denna artikel handlar om offentlig amning i Finland idag och på vilka sätt den ammande kroppen uppfattas som problematisk av de som själva ammar. Ledfrågorna har varit i vilka situationer kroppen uppfattas som ett problem och vad det är som gör att kroppen upplevs som ett problem just då. Det finns väldigt lite forskning 
om offentlig amning i den finska kulturen, men enligt en studie om föräldrars attityder till amning anses offentlig amning ändå vara accepterat av majoriteten (Laanterä et al. 2010). Det innebär inte att det är oproblematiskt. Offentlig amning förknippas ändå med känslor av obekvämhet för de som ammar (Metsämäki 2018:56ff). Också i ovannämnda studie var det en tredjedel av de svarande som inte ansåg det vara okej att amma en ettåring på en hamburgerrestaurang (Laanterä et al. 2010), vilket visar på en spridning i attityderna.

Syftet med denna artikel är att utgående ifrån känslan av att vara obekväm, undersöka vilka problem den ammande kroppen stöter på i det offentliga rummet. När upplevs den ammande kroppen som obekväm och hur tar det sig uttryck? Vilka andra känslouttryck hänger ihop med känslan av att vara obekväm och vad gör dessa känslor? Vilka strategier aktiveras då den ammande kvinnan rör sig i offentliga rum?

Offentlig amning kan definieras på olika sätt (se t.ex. Owens et al. 2016) och det offentliga konstrueras på olika sätt i intervjuerna. Jag har valt att i denna artikel använda en bred definition där offentlig amning inkluderar både amning på offentliga platser, amning i hemmet med utomstående personer närvarande och amning på privata platser utanför det egna hemmet. Detta val grundar sig i vad informanterna berättade under intervjuerna.

Materialet består av inspelningar av fem intervjuer ${ }^{1}$ om offentlig amning som gjordes inför min kandidatavhandling år 2013 (en intervju) och min avhandling pro gradu 2016 (fyra intervjuer), och kommentarer på en artikel om offentlig amning publicerad på Svenska Yles webbsidor (Häggman 2017). Alla intervjuer är gjorda i Åbo med kvinnor som vid tidpunkten för intervjun var bosatta i där. Kvinnorna hade ammat i någon form under se senaste två åren före intervjun, och många av kvinnorna ammade ännu i intervjuskedet. En del av kvinnorna hade ett barn och en del av kvinnorna hade två barn. Sammanlagt hade de ammat sju barn. Jag sökte specifikt efter svensktalande kvinnor bosatta i Finland. Den första kvinnan tillfrågades personligen, medan de andra fyra svarade på 
en förfrågan i en Facebookgrupp för Folkhälsans familjecafé i Åbo². Alla kvinnor var vita, i 30-årsåldern och hade en högre utbildning. Alla fem bodde tillsammans med barnets andra förälder, varav fyra identifierades som pappor och en som mamma. De utgjorde således en mycket homogen grupp.

Den 25 juli 2017 publicerade Åborestaurangen Aune ett inlägg på sin Facebooksida där de förklarar sitt beslut att hänvisa ammande mammor till ett amningsrum. De menade att matgäster störs av de ammande mammorna och att de därför inrättat ett litet amningsrum i anslutning till toaletterna (Restaurang Aunes Facebooksida). Detta inlägg väckte stor uppmärksamhet och delades över 300 gånger och fick över 4000 kommentarer. Svenska Yle skrev sedan en artikel om händelsen (Häggman 2017), som i sin tur fick 92 kommentarer. Det är kommentarerna till Yle-artikeln som jag inkluderat i mitt material, med tanken att det ger en bild av de attityder till offentlig amning som fanns i Svenskfinland år 2017. Inställningen till offentlig amning är varierande bland kommentatorerna. Vissa försvarar den offentliga amningen medan andra är negativt inställda.

De intervjuade kvinnorna har i artikeln fătt fingerade namn för att anonymisera dem men ändå göra läsningen mer angenäm. Citaten är skrivna på standardsvenska och vissa upprepningar eller stakningar har redigerats bort. Kommentarerna på artikeln har citerats som de är, utan några redigeringar. Stavfel eller grammatikfel har inte rättats till och där de förekommer har de också funnits i originalet. Jag hänvisar till Svenska Yles kommentarsfält för att särskilja dessa citat från intervjucitaten, men dessa citat bör inte förstås som en och samma person.

Materialet har analyserats med hjälp av en kulturanalytisk närläsning. Närläsning är en metod som går ut på upprepade genomgångar av ett material, där man försöker hitta kulturella mönster. Forskaren förlitar sig på sin egen kunskap och erfarenhet och varje läsning bygger på tidigare läsningar (Henriksson 2007:35, 37). Kulturanalys kan användas som redskap för att granska maktstrukturer och belysa hur normer verkar (Nilsson \& Marander-Eklund 2018:3). I 
denna undersökning ligger fokus närmast på normbrott, och vilka kategorier som aktualiseras i de situationer som av informanterna uppfattas som problem.

Jag har i närläsningen fokuserat på emotioner, närmare bestämt en känsla av att vara obekväm. En känsla kan beskrivas som den personliga upplevelsen av kvaliteter som sorg, kärlek eller skam (Shouse 2005). Emotioner kan i sin tur förstås som sociala, historiska och kulturella praktiker (Öhman, Jönsson \& Svensson 2011:11). Även om det jag studerar närmast kan beskrivas som emotioner, har jag valt att i denna artikel använda begreppen emotion och känsla som synonyma. Detta val har jag gjort av två anledningar. Den ena anledningen är att emotioner är ett klumpigt begrepp på svenska, och den andra är att ordet känsla bättre fångar in att det är något som känns och finns i kroppen.

Att studera känslor är inte helt oproblematiskt. Det är svårt att klart avgränsa känslor från varandra. Det en person beskriver som att vara obekväm är inte nödvändigtvis detsamma som det någon annan menar. Alla informanter är heller inte obekväma i samma situationer, och en av informanterna uppgav att hon för det mesta inte var obekväm med att amma offentligt.

Inspirerad av Sara Ahmed ligger mitt fokus på vad känslor gör, snarare än vad de är. Emotioner hänger ihop med rörelse, de får kroppar att röra sig bort eller emot varandra och hänger ihop med hur kroppar rör sig i rummet. Det handlar dock inte bara om rörelse utan också om vad som håller oss kvar (Ahmed 2004b:11). Känslor är enligt Ahmed också riktade och relationella (Ahmed 2004b:8), man är exempelvis inte bara rädd utan man är rädd för något. Känslor bör heller inte förstås som något som kommer varken "inifrån" eller "utifrån", utan som något som definierar de världar som befolkas av subjekt (Ahmed 2004a:25).

Känslan av att vara obekväm uttrycks i intervjuerna på lite olika sätt, även om just ordet obekväm kanske är det som förekommer mest och som jag utgått ifrån. Men det handlar också om situationer de beskriver som pinsamma eller jobbiga. Ibland förknippas 
det obekväma med andra känslor som äckel, rädsla eller smärta. Ibland handlar det bara om att de inte känner sig bekväma, eller att något är obehändigt. Gemensamt är ändå att det är något som uppfattas som problematiskt av någon anledning. Många av informanternas handlingar i samband med offentlig amning handlar om att minska denna känsla av att var obekväm, även om den sällan eller aldrig helt försvinner. Det bör dock poängteras att offentlig amning inte enbart förknippas med negativa känslor, även om det är mycket framträdande i flera av intervjuerna. Jag har valt att i denna undersökning utgå ifrån känslan av att vara obekväm för att lyfta fram problem som den ammande kroppen stöter på. Det betyder inte att erfarenheten av offentlig amning enbart präglas av problem eller negativa känslor, tvärtom kunde den också kopplas ihop med känslor av frihet, stolthet och närhet.

Sara Ahmed beskriver känslan av att vara bekväm som en känsla av att höra hemma i världen, en känsla som kanske bara märks då den försvinner. Hon beskriver också känslan av att vara bekväm som att vara orienterad (Ahmed 2010:59). Orientering handlar för Ahmed om att göra det okända bekant genom kropparnas förlängning i rummet. Sara Ahmed beskriver rummet som en förlängning av vissa sorters kroppar (Ahmed 2006:11). Med utgångspunkt i detta kan man tolka denna känsla av obekvämhet som att vissa rum inte är en förlängning av den ammande kroppen. Att informanterna ändå ammade offentligt trots en känsla av obekvämhet handlade dels om att de kunde använda sig av strategier för att göra amningen mer osynlig, men kan också ha att göra med att de alla var vita kvinnor med högre utbildning. Informanterna kan sägas tillhöra en samhällsklass som är van vid att ta plats i offentliga utrymmen och som utgår ifrån att det offentliga rummet är till för dem, och rör sig således med en självklarhet som inte är alla kvinnor förunnat. Forskning från flera länder visar att amning och offentlig amning är relaterat till klass, där kvinnor med lägre utbildning och lägre inkomstnivå ammar mindre (Callen \& Pinelli 2004, Uusitalo et al. 2012, Socialstyrelsen 2014) och upplever offentlig amning som mer problematiskt (Johnston \& Robledo 2007). 
Att jag väljer att tala om den ammande kroppen är ingen slump, och kan till och med tyckas lite märkligt, då den ammande kroppen egentligen är en socialt kodad kvinnokropp som utför en specifik handling. Den obekvämhet som erfars handlar alltså (för det mesta) om situationen då de ammar, inte när de rör sig i världen utan att amma, även om det i biologisk mening fortfarande är en ammande kropp som rör sig, det vill säga en kropp vars bröst producerar mjölk. Det är dock inte uteslutande själva amningssituationen som är problematisk, utan valet att tala om just den ammande kroppen som en speciell sorts kropp handlar om just denna kroppsliga oförutsägbarhet. Utöver själva amningssituationen kan det uppstå problemsituationer med läckande mjölk eller utpumpning av mjölk. Det är alltså när den ammande kroppen avslöjas som just en ammande kropp som problemen uppstår. Inspirerad av Kate Boyer ser jag på den ammande kroppen som dynamisk och interagerande (Boyer 2018:1, se också Grosz 1994:209).

Det offentliga rummet är heller inte statiskt och olika rum upplevs som mer eller mindre obekväma för informanterna. Makt och rum är kopplat till varandra och hur kroppar har rätt att ta plats i rummet påverkas av rådande maktstrukturer (Ehn och Löfgren 2001:98, Svensson 2009:24, 28). Inom platsforskning görs ofta en skillnad mellan de engelska begreppen space och place, där space står för den rumsliga dimensionen medan place är laddat med betydelser (Tuan 1979). I denna artikel kommer jag att skriva om rum och plats, där rum kan förstås som rumslighet i en mer abstrakt mening, medan en plats är en specifik plats som är laddad med kulturella innebörder.

Rummet påverkar alltså kropparna och vad som upplevs som korrekt beteende på olika platser. Kroppar påverkar dock också rummet, där vissa kroppar gör att den offentliga amningen upplevs som mer bekväm, medan andra kroppar gör informanterna obekväma. Vissa kroppar kan till och med förvandla en annars privat plats som hemmet till offentlig i termer av hur obekväma med amningen informanterna känner sig. Skillnaderna mellan dessa platser upplevdes mycket handla om ifall platserna var vända till småbarn eller 
inte. Familjecaféer, rådgivningar eller utrymmen speciellt ägnade åt barn i till exempel köpcentrum upplevdes som mer amningsvänliga.

\section{Bröstet, eller konflikten mellan sexualitet och moderskap}

Flera av kvinnorna jag intervjuat uppgav att de i någon mån kände sig obekväma då de ammade offentligt. Endast Lisa verkade helt bekväm med att amma offentligt, även om hon också sade sig kunna tycka offentlig amning hade varit obekvämt om hon hade varit tvungen att blotta en stor del av kroppen (vilket hon inte kände sig tvungen att göra). Beroende på situation kände kvinnorna sig mer eller mindre obekväma, men med undantag av Lisa föredrog de ändå alltid att amma hemma. Trots detta valde de ändå att amma offentligt, till vilket man kunde ställa frågan varför? Idag finns ändå alternativ som att ge ersättning eller bröstmjölk på flaska, och som några i kommentarsfältet antydde finns också alternativet att den ammande kvinnan stannar hemma den period det rör sig om.

Detta handlar till viss del om att informanterna tyckte att amning var någonting som skulle lyftas fram i samhället. De menade att amning var något som borde få synas och var beredda att trotsa sin egen känsla av att vara obekväm för att amma offentligt, något som citatet nedan exemplifierar.

Jag tycker det är kanske lite jobbigt att amma offentligt, men jag ammar ändå. Och jag tycker att det är jättefint att folk ammar offentligt. Det är jätteroligt att se att andra också ammar på café, så jag tycker att det är jättekiva att folk ammar offentligt, för det ska det nog göras tycker jag, att man ska inte som gå omkring och gömma det (Kajsa IF mgt 2017/073)

Kajsa vill gärna att amning ska synas i samhället, och det att alla skulle kunna amma var de ville och känna sig bekväma med det var också en önskan som flera informanter uttryckte i intervjuerna. De 
menade dock att detta inte var fallet i nuläget, även om det ändå var självklart för dem att amma offentligt.

Det kunde också handla om att de inte såg några alternativ till att amma offentligt. Även om de upplevde det som obekvämt var den offentliga amningen det alternativ som framstod som det bästa, ofta eftersom de inte gärna ville ge flaska eller hade försökt men inte fått det att fungera. Mina informanter uppfattade amningen som en central del av att vara goda mödrar. Diskursen "bröst är bäst" är en vanligt förekommande diskurs gällande amning kontra flaskmatning (Murphy 1999, Callaghan \& Lazard 2012). Denna diskurs positionerar amning som det optimala sättet att ge barn mat och framhåller också amningens naturlighet, i motsats till flaskmatning med ersättning som ses som sämre och onaturligt (Callaghan \& Lazard 2012:939f). Flera informanter betonade bröstmjölkens hälsofrämjande egenskaper med hänvisning till forskning. De framhöll också amningens naturlighet. De hade alla försökt amma eftersom de ansåg att det var det bästa för barnet. Detta innebar också att de ville amma offentligt för barnets skull, även om de själva uppfattade det som obekvämt.

De uttryckte en stolthet över amningen och att vara en ammande mor var en position de gärna innehade. Amningen förknippades också för flera informanter med trygghet och närhet och lugn. Dock kunde det också vara förknippat med smärta, något jag återkommer till senare. Detta lugn var ändå inte karakteristiskt för den offentliga amningen och rollen som en god mor var inte oproblematisk att upprätthålla i samband med den offentliga amningen (jfr Stearns 1999). I den västerländska kulturen förknippas moderskapet med egenskaper såsom omvårdnad, kärleksfullhet, uppoffring, ansvarsfullhet och osjälviskhet (Longhurst 2008:6). Gällande brösten finns dock en dualitet, där det ammande bröstet förstås som moderligt, samtidigt som bröstet i den västerländska kulturen är starkt kopplad till sexualitet, något som är oförenligt med idealet om den goda modern (Young 1998:130f). Detta innebar en konflikt som informanterna behövde lösa, och för att göra detta använde de sig av olika strategier. 
En av dessa strategier var att använda sig av speciella kläder eller sjalar som gjorde så att bröstet inte skulle synas för utomstående. En annan strategi var att vända sig bort från andra eller placera sig i rummet så att kroppen var skyddad från insyn. Informanterna kunde också söka sig till vissa platser som de ansåg vara mer lämpliga att amma på, som amningsrum eller skötrum. Det handlade delvis om att försöka göra själva amningen så osynlig som möjligt, men också om att undvika en sexualiserande blick. Julia nämnde att hon brukade använda sig av en sjal då hon ammade offentligt, både för barnets skull och hennes egen skull. Då jag ställde en följdfråga om på vilket sätt det var för hennes egen skull svarade hon:

För min egen skull just det där att man vet inte om det kan finnas någon laddning hos någon annan som ser den här amningen som har liksom en sexuell laddning. Man har ändå hört, ja, jag vet inte var eller när jag har hört talas om det men det har funnits fall då en mansperson kan ha blivit såhär upphetsad av det här att det finns ett bröst framme som ammar ett barn, och jag vill inte ens ta en risk att man skulle behöva vara med om någonting sådant. För jag vet ju att jag skulle bli oerhört äcklad av det, ens tanken på det att en man, eller att någon kan bli upphetsad av en sådan grej. Eftersom att det för en själv är så långt ifrån det där sexuella i det skedet att man sitter och ammar sitt barn (Julia IF mgt 2017/075)

Julia uttrycker känslor av äckel i samband med tanken på att någon skulle se amningen och uppfatta det som något sexuellt, något hon menar att amning inte alls handlar om. Äckel är en väldigt stark känsla, och här förstärker hon den ytterligare med att säga att hon skulle bli oerhört äcklad istället för enbart äcklad. Äckel är en känsla som är starkt sammankopplad med maktrelationer (Ahmed 2004b:88). Känslan innefattar både en dragning mot något samt en rörelse bort från det man finner äckligt. I detta fall tolkar jag informantens uttryck av äckel som ett sätt att ta avstånd från hela tanken att amning skulle kunna vara sexuellt. Samtidigt gör denna känsla att hon går till konkret handling och skyler sig. Den potentiellt upphetsade mannen, eller personen, utgör en såpass stark påverkan att bara förekomsten av en tanke på hennes bröst 
som sexuellt i amningssituationen utgör ett hot. Detta visar på en central aspekt då det kommer till det problematiska med offentlig amning ur de ammandes synvinkel. Att bli uppfattad som sexuell i amningssituationen upplevs som obehagligt och är något hon till varje pris vill undvika. Detta handlar troligtvis dels om incesttabut, om någon annan uppfattar henne som sexuell kanske situationen är sexuell vilket den i den västerländska kulturen inte får vara då den innefattar mor och barn. Samtidigt uppkommer tanken på incest av bröstets sexuella laddning. Marion Young skriver "[b]reasts are a scandal because they shatter the border between motherhood and sexuality" (Young 1998:133). Hon menar att upprätthållandet av gränsen mellan moderskap och en erotisk sexualitet är grundläggande i ett västerländskt patriarkalt samhälle. En sexuell tolkning av amningen skulle således upplösa denna gräns.

Det är ändå den upphetsade mannen som ses som avvikande och konstig i sammanhanget för mina informanter och många i kommentarsfältet. Det finns dock också kommentarer som anspelar på att män inte borde ha något emot att se ammande kvinnor just på grund av att män vill se bröst (som de förutsätts bli attraherade av). Man kan ändå konstatera att det är min informant som går till konkret handling för att undvika att situationen uppstår. Även om min informant inte pratar om några konkreta övergrepp, är logiken mycket lik den som gäller när det kommer till just sexuella övergrepp. Detta framkommer också då en kommentator drar paralleller till just sexuella övergrepp på kvinnor:

Hävdar ni att ni bestämmer över er kropp i detta sammanhang så betyder det att ni vill visa upp er. Samma argumentet brukar komma fram när tjejer blir kritiserade för att det är för lättklädda och blir antastade. Det är inte så enkelt som att man själv kan bestämma allting för det finns andra människor som kan ta illa upp, eller bete sig illa pga alkohol eller droger. Sånt måste man förstå att kan hända om man är utmanande, medvetet eller omedvetet. (Svenska Yles kommentarsfält)

Här läggs ansvaret för att förhindra omgivningens oönskade beteende på kvinnan, både vad det gäller offentlig amning och sexu- 
ella övergrepp. Dessa citat säger inte bara något om kvinnors sexualitet, där det är på kvinnans ansvar att se till att inte uppfattas som sexuell i mäns ögon om hon inte vill det, utan de säger också något om mäns sexualitet. Män förutsätts vara sexuellt attraherade av kvinnobröst i alla situationer och inte kunna hjälpa att de tittar då tillfälle ges. Mäns sexualitet är stark, okontrollerbar och allestädes närvarande och därför är det kvinnors ansvar att reglera sina kroppar för att inte väcka mannens lustar. I detta fall pekas på alkohol eller droger i kombination med lättklädda kvinnor som orsak. Förövarens ansvar lyser dock med sin frånvaro.

Att sexuella övergrepp dyker upp i en diskussion om offentlig amning kan tyckas lite märkligt. Samtidigt bygger båda diskussionerna på föreställningen om kvinnan som hora eller madonna (jmf Wennstam 2002). Det är horan som blir våldtagen, och den ammande kvinnan som inte skyler sig tillräckligt riskerar att stämplas som sexuell. Det är alltså inte det faktum att bröstet syns som väcker obehag i sig, utan denna känsla är sammankopplad med föreställningar om bröst och kvinnlighet och moderskap.

\section{"Jag är kanske obekväm med att göra folk obekväma": egna och andras känslor}

Det var inte bara informanterna som kunde känna sig obekväma, utan också människor runt omkring den som ammade. I intervjuerna framkom dels att informanterna kunde känna sig obekväma när andra ammade, men också att de föreställde sig att människor runt omkring dem blev obekväma när de ammade. I de fall informanterna själva pratade om att de kunde bli obekväma rörde det sig om amning av äldre barn, något jag återkommer till senare.

De berättade också om att upplevelsen hos den som själv ammade kunde göra så att andra personer blev obekväma. Var personen som ammade själv obekväm ledde det i sin tur till att personerna runt omkring blev obekväma. Kunde personen däremot hantera det hela bra och verkade tillräckligt självsäker kunde en situation 
som i vanliga fall skulle upplevas som väldigt obekväm, till exempel att ett äldre barn kom och "grävde fram" (Ines IF mgt 2017/074) mammans bröst för att amma, uppfattas som behaglig för alla inblandade.

Informanterna var också väldigt medvetna om andra människors känslor när de ammade. En stor del av det som informanterna upplevde som obekvämt hängde ihop med föreställningar om vad andra människor tänkte och kände i situationen. Nedan beskriver Kajsa varför hon helst inte ammat offentligt. Hon nämner här en annan känsla som verkar hänga ihop med känslan av att vara obekväm, nämligen rädsla.

Jag är kanske delvis också lite rädd för att det kommer någon sådan här sur gubbe och tycker att jag inte ska amma. Det har inte hänt, men man har ju hört. Och jag vet inte som, kanske att jag vet som inte vad jag skulle säga åt den sura gubben eller tanten. Jag tänker mig att det är sur gubbe på något sätt. Mmm. Det är kanske det som jag är mest sådär, jag är kanske obekväm med att göra folk obekväma (Kajsa IF mgt 2017/073)

Bara några sekunder senare förtydligar hon att det hon är rädd för är negativ kritik. Sara Ahmed menar att rädsla innefattar en temporal dimension, man är rädd för något som ska hända i framtiden, men förväntar sig att det ska uppstå någon form av obehag (Ahmed 2004b:65). I detta exempel är Kajsa rädd för att andra inte ska tycka om att hon ammar, men mest rädd är hon för att de andra personerna ska ge uttryck för detta. Hon föreställer sig alltså obehaget av att någon ska kommentera negativt på hennes amning, vilket gör att hon uttrycker att hon blir rädd. Även om hon på ett väldigt träffande sätt beskriver att hon är obekväm med att göra folk obekväma, är det karaktäristiska med just hennes intervju att hon samtidigt menar att den som är obekväm med hennes ammande får väl vara det då. Hon ammar så att säga igenom sin egen och andras känsla av obekvämhet.

Att hon är mest rädd för att andra ska kommentera eller ge uttryck för sina negativa åsikter tolkar jag som att det i känslan obekväm 
ligger en sorts skamkänsla över ett normbrott och hon är rädd för att bli utpekad. Skam som känsla är inte alls särskilt framträdande i intervjuerna. När den nämns är det oftast för att påpeka att de inte skäms över sin amning, eller att en situation inte varit pinsam. Samtidigt finns tanken om att de hade kunnat vara något att skämmas för där, annars hade de inte behövt poängtera att de inte upplever skam eller pinsamhet, som kan tolkas som en sorts social skamkänsla. Skammen ligger alltså ändå nära tillhands i en situation som offentlig amning. Det är lätt att göra fel, och bli utpekad för detta. Skam hänger mycket ihop med "att dölja" och "att bli avslöjad" (Ahmed 2004b: 103-104). Flera informanter nämner att de är oroliga för att få negativa kommentarer av andra. Det de upplever som jobbigt med den offentliga amningen är det att man syns så mycket. Skam gör att man försöker gömma sig för den andres blick. Skam kan också upplevas som den känslomässiga kostnaden för att inte leva enligt normativa livsmanus (Ahmed 2004b:103-104).

Något annat man kan utläsa ur citatet ovan är att hon föreställer sig en "sur gubbe". Detta säger också något om vilka känslor andra föreställs ha, gubben är "sur", något som anspelar på ilska. Detta förekommer också i andra intervjuer, till exempel Ines som pratar om "ilskna kommentarer". Amning i offentligheten är alltså något som för informanterna kan tänkas väcka ilska hos omgivningen. Hon är också tydlig med att hon föreställer sig en gubbe, i motsats till tant. Både ordet "tant" och "gubbe" syftar till en äldre person, och en gubbe är en äldre man. Gubben är i detta fall intressant, eftersom det egentligen inte behöver vara just en gubbe. Hon är inte rädd för själva gubben, utan för att bli utpekad för att amma på ett negativt sätt.

Att det är just en äldre man som är föremålet för rädslan är ändå troligtvis ingen slump, och det är heller ingenting unikt för denna informant. Tvärtom är denna föreställning, att de som är emot offentlig amning är äldre personer och framför allt män, något som förekommer i alla intervjuer. Ines nämner exempelvis att hon skulle känna sig obekväm med att amma om hon satt bredvid en äldre man på ett flygplan. Den typiska motståndaren till offentlig amning 
beskrivs oftast som en äldre man, något som säger mer om vilka föreställningar som förknippas med äldre män, än om att gruppen äldre män skulle vara mer emot amning än någon annan grupp, något tidigare forskning visat att inte är fallet (Acker 2009:482-483). I detta fall får den äldre mannen stå för tillbakasträvande och konservativa värderingar. Det dras också paralleller till en diskussion om jämställdhet, där den äldre mannen förväntas vara emot detta, något som också dyker upp i kommenarsfältet i form av kommentarer om att de som kommenterar negativt måste vara män. Denna äldre man är dock ingen figur som informanterna anser att de behöver ta särskild hänsyn till, utan han avfärdas ofta som överdriven i sina reaktioner. Detta sker ofta med hänvisning till att den offentliga amningen är så diskret.

Diskretion var det sätt som informanterna oftast valde att hantera en obekväm omgivning på. Detta kan tolkas som en effekt av rädslan på kroppen. Rädsla innebär enligt Ahmed att kroppen krymper ihop (Ahmed 2004b:69), vilket är precis vad informanterna gör när de beskriver att de är diskreta. Att vara diskret innebär att ta upp mindre plats. Rädsla gör att vissa kroppar begränsas av att andras kroppar tar upp mer plats (Ahmed 2004b:69). Informanternas val att vara mer diskreta eller lämna rummet kan tolkas som just detta. Informanterna reglerar sig själva och låter sina kroppar ta mindre utrymme vilket leder till att andra kroppar får mer utrymme.

I detta avseende stack Kajsa, informanten jag citerade ovan, lite ut. Inte för att hon skulle ha varit omedveten om andras känslor eller för att hon inte skulle vara diskret, men för att hon vägrade låta sig styras av sin egen känsla av att vara obekväm eller att hon gjorde andra obekväma. Hon gjorde alltså ett medvetet beslut att vara mindre diskret än vad hon kände att hon hade velat vara.

Här ser man tydligt hur kroppar, känslor och platser samverkar och påverkar varandra (jmf Longhurst 2001). Kropparna som är närvarande kan göra en plats mer eller mindre amningsvänlig. Det mest tydliga exemplet på detta är den sura gubben som gör en plats mindre amningsvänlig och andra ammande mammor som gör den mer amningsvänlig. Platsen påverkar hur obekväma de ammande 
kvinnorna känner sig och också hur benägna de är att faktiskt amma på en viss plats.

Kate Boyer har studerat hur främlingar påverkar kvinnors upplevelse av offentlig amning i Storbritannien. Hon konstaterar dels att vissa kvinnor undviker att amma offentligt för att undvika den pinsamhet som möten med främlingar kan innebära. Hon för även fram att mödrar, utöver att se till att det egna barnet har det bra, också förväntas sköta om andra människors känslor, vilket inkluderar främlingar (Boyer 2016:38). Pressen att ta andras känslor i beaktande kan spela stor roll då det kommer till att forma människors beteende. Detta behöver inte alltid vara ett medvetet beslut från den ammande kvinnans sida. Anna uttrycker sig såhär om att amma med människor på besök:

Och sen kanske jag inte har tänkt på det, det är liksom mera det att vissa gånger så känns det att nu går jag till sovrummet och ammar och vissa gånger känns det som att nu tänker jag sitta här. Det är inte sådär jätte medvetet beslut heller (Anna IF mgt 2017/072)

Hon använder sig här av ordet känns, det är känslan i stunden som avgör, en känsla som säkerligen är påverkad av flera faktorer, men det är inget hon tänker på i stunden utan detta sker omedvetet. Detta är ändå ett utmärkt exempel på hur en viss självreglering äger rum utifrån känslor.

\section{Kroppslighet bortom kontroll}

Äckel var också en känsla som tillskrevs andra människor. Detta trots att informanterna själva inte ansåg att amning var äckligt och ställde sig kritiska till att någon skulle tycka det. Detta tolkade informanten Anna som att det kroppsliga i allmänhet ses som äckligt $\mathrm{i}$ vårt samhälle, det som kroppen producerar ses som "slaggprodukter" (Anna IF mgt 2017/072). I relation till amning är det bröstmjölken som är en kroppslig utsöndring som därmed kunde tänkas väcka äckelkänslor hos omgivningen. Också i 
kommentarsfältet gjordes paralleller till urin och avföring där att amma offentligt jämfördes med att kissa eller bajsa offentligt. Det är kroppsvätskor som i vanliga fall förknippas med en viss äckelkänsla.

Bröstmjölken var något som måste hanteras, och inte bara under själva amningssituationen. Mellan amningsgångerna kunde brösten läcka och orsaka att informanten kände sig obekväm. Ines berättar om en situation där hon varit med om just detta:

Plus att man måste alltid komma ihåg att ha med alla möjliga sådana här pads för att det läckte jättemycket mjölk då under det här första halvåret åtminstone, nog ännu alltså dom första nio månaderna säkert, så att vid något skede minns jag nog att jag har bytt t-skjorta på tågets vessa. Då hade han sovit liksom förbi ett sådant här amningspass, eller det tyckte mina bröst $\mathrm{i}$ alla fall, för att sen hade det läckt liksom igenom dom där padsen som jag hade i behån och sen började [jag] märka att det är liksom sådana här stora våta märken på t-skjortan, så då kändes det liksom obekvämt (Ines IF mgt 2017/074)

Bröstmjölken kunde alltså vara en källa till problem, i synnerhet om den hamnade på fel ställe. Rätt ställe var i bröstet eller i barnets mun eller mage. Fläckar på skjortan upplevdes som pinsamt eller obekvämt och att bröstmjölken "skvätte" omkring var heller inte önskvärt. Kroppsvätskor anses ofta som pinsamma i den västerländska kulturen (Longhurst 2001: 30). Den kvinnliga kroppen kopplas ofta ihop med fluiditet och instabila gränser jämfört med den manliga kroppen som föreställs vara fast (Grosz 1994: 203, Longhurst 2001: 2,30). Läckor visar på kroppens ofrånkomliga materialitet (Grosz 1994:194), och kan ses som ett sätt som materian "sparkar tillbaka" (Barad 1996:116). Det är något som står utanför vår kontroll, ett sätt som kroppen ger sig tillkänna. Detta står dock emot uppfattningen att kroppen är enhetlig och fast, något som kan bidra till att den reproduktiva kroppen upplevs som hotfull i offentligheten (jfr Lane 2014:197). Den stör den givna ordningen om hur kroppar föreställs vara (jfr Douglas 1997:54-56). 
Bröstmjölken kan på detta vis ses som en agent (jfr Boyer 2018). Mjölken går inte helt att kontrollera och är en del av den ammande kroppen. Det obekväma som mina informanter beskriver rör sig mest om mjölk som är "överallt", och upplevelsen av att ha för mycket mjölk. Men en av informanterna hade också upplevt det motsatta, nämligen att ha för lite mjölk. Lisa hade aldrig kunnat helamma trots att hon väldigt gärna hade velat. Intressant här är att hon ändå valde att amma offentligt, trots att det troligtvis skulle ha varit mycket lätt för henne att enbart flaskmata i offentligheten, något andra informanter uppgav att de skulle ha gjort om de hade fått det att fungera. För Lisa verkade dock den offentliga amningen vara väldigt oproblematisk i stort och för henne var det viktigaste att hennes barn fick amma i så stor utsträckning som möjligt. Bröstmjölken visar ändå på den oberäknelighet som kroppen bjuder på. Mjölken kan spruta omkring och hamna i kläderna eller på andra olämpliga platser, eller så kan den kanske inte komma alls.

I den offentliga debatten kring offentlig amning görs ibland jämförelser till att rapa och fisa samt att ha sex offentligt (Svenska Yles kommentarsfält). Här rör det sig inte nödvändigtvis om några kroppsvätskor, även om att fisa och rapa är väldigt kroppsliga funktioner som ändå anses opassande bland folk. Parallellen till att ha sex offentligt är intressant eftersom det är just dessa sexuella konnotationer som informanterna är så obekväma med. Samtidigt förekommer kommentarer, som denna nedan som svarar till en person som menar att amning nog drar till sig uppmärksamhet och att man därför inte kan kräva att få amma var som helst:

Nej, det drar inte alls till sig uppmärksamhet, amning är det mest avsexualiserade som finns (Svenska Yles kommentarsfält)

Det är intressant att personen som svarar förutsätter att det är fråga om sexuell uppmärksamhet, eftersom detta inte alls nämns i den första kommentaren. Att amning är det mest avsexualiserade som finns säger också något om vår syn på sexualitet, och vad som får ses på som sexuellt. Detta visar på den svåra balansgång informanterna går på då de ammar offentligt. Å ena sidan utgår man från att amning leder tankarna till sex och det görs jämförelser till att ha 
sex offentligt. Å andra sidan bör amningen vara något helt frånskilt från det sexuella.

Amning kunde också vara förknippad med smärta, vilket innebar extra problem i det offentliga. I synnerhet Kajsa pratade mycket om smärta, då amningen hade varit mycket problemfylld för henne och gjort ont under en lång tid. Hon ville inte gärna visa att det gjorde ont, utan försökte istället undvika att amma inför främmande då det gjorde som mest ont, samt inte visa att det gjorde ont då hon ammade offentligt. Ahmed menar att smärta formar kroppen både som materialitet och som levd entitet (Ahmed 2004:24). Via smärtan känner vi av kroppens gränser, var den börjar och slutar. Detta gör att kroppen kommer i fokus, specifikt bröstet som hon känner smärtan $\mathrm{i}$, något som mycket väl kan tänkas innebära problem då bröstvårtan helst inte skulle synas alls under amningen. Elizabeth Grosz skriver att de delar som påverkas av smärta förstoras i den egna bilden av kroppen (Grosz 1994:76). För att hantera smärtan och kunna amma använde sig informanten av ett amningsvårtskydd $^{3}$, något som ytterligare försvårade för henne att vara diskret, då skyddet skulle sättas på och tas av före och efter amningen.

Uttrycken för känslan av smärta verkade tillhöra det mest privata, något som i sin tur gör att även problemfylld amning kan framstå som en ideal amning i det offentliga. Kajsa berättade flera gånger om att andra antagligen uppfattade henne som mera oberörd än vad hon verkligen var när hon ammade offentligt. Hon menade att amningen hade uppfattats av andra som lättare för henne än vad den i verkligheten varit. Kajsa upplevde att hon verkligen hade kämpat för en fungerande amning och inte gett upp som många andra i hennes närhet gjort. Jag tolkar detta som att en bild av att hon inte fătt erkännande för det arbete hon gjort kröp fram under intervjun.

Uppfattningen att amning som arbete osynliggörs är ingenting nytt (jfr Dahl 2004). Arbetet med att vara diskret vid offentlig amning bidrar både till att öka på kvinnors arbetsbörda gällande amningen samt osynliggöra själva arbetet de utför (Stearns 1999:323). Upprätthållandet av bilden av att amning är problemfritt och bara går 
av sig självt bidrar förstås till detta, samtidigt som amning är starkt kopplat till kvinnlighet och att kroppen "fungerar som den ska". Kvinnor som visar att amningen inte är problemfri tar en viss risk. Deras kroppar fungerar inte som en riktig kvinnokropp ska göra enligt normen.

\section{Amning utanför normen}

Något alla informanter nämnde som extra problematiskt var att amma ett äldre barn i offentligheten. Det de definierade som äldre barn var barn som började vara en bit över ett år gammalt. De argument som informanterna tidigare använt sig av för att försvara sitt offentliga ammande gällde inte längre när det kom till äldre barn. Argumenten som framfördes handlade oftast om barnets rätt till att få äta var det ville, snarare än kvinnans rätt att amma var hon ville. Men eftersom barn som är äldre än spädbarn också förväntas kunna äta annan mat, var det inte längre självklart att använda sig av barnets rätt till mat som ett argument då det kom till äldre barn. Många av kvinnorna hade valt att sluta amma innan de befann sig i en situation där de behövde fundera över om de skulle fortsätta amma offentligt eller inte, men vissa hade valt att fortsätta amma. De berättade att de plötsligt blivit mer medvetna om sig själva när de ammade offentligt när barnet blivit äldre. De uppfattade att även människor som tyckte det var okej att amma spädbarn i offentligheten kunde tycka att det var opassande att amma ett äldre barn.

Ines ammade vid intervjutillfället ännu sitt barn som då var kring ett och ett halvt år och berättade att hon då barnet fyllde ett år, började fundera mer över sin amning. Ines hade färdiga argument för att försvara amningen ifall någon skulle ifrågasätta den. Exempelvis argument som att det är bra för immunförsvaret när barnet börjat dagvård. Mycket av problematiken kring att amma äldre barn verkade handla om att amningen blev lustbetonad snarare än matbetonad. Ines säger så här om att amma offentligt:

Att just sådant här som man nu ändå kan hemma ibland göra att man nu liksom har brösten där och så blir man såhär och leker 
med barnet, så sånt gör man ju inte i offentlighet. Att det är snarare som såhär okej, näring, tack [skratt]. Sen nästa punkt på något sätt. Att det är nog bara det där näringsmässiga och inte så mycket närhet och cuddles... (Ines IF mgt 2017/074)

Amning i offentlighet handlar enligt henne om att barnet ska få i sig näringen som bröstmjölken erbjuder, medan de andra delarna som att mysa, leka och vara nära är sådana som hon helst vill undvika $\mathrm{i}$ det offentliga. I citatet ovan pratar hon inte om specifikt äldre barn, utan om offentlig amning i allmänhet. Det är ändå relaterat såtillvida att amningen med äldre barn handlar mindre om näring och mer om just närheten och relationen.

Här framkommer ännu en norm, nämligen den att i synnerhet den offentliga amningen, inte ska göras för gärna. Amning är något som görs för barnets skull, inte mammans egen, vilket stämmer väl överens med ett osjälviskt och uppoffrande moderskapsideal. Långtidsammande mammor ses ibland som egoistiska och till och med perversa (Hamréus \& Ivanoff 2010). Denna föreställning var inte något som mina informanter gav uttryck för och det framkom inte heller bland kommentarerna. Ändå var det till viss del något som de informanter som hade ammat längre försvarade sig mot genom att betona att det fortfarande handlade om barnets bästa, inte deras egen njutning. Det kunde handla om att barnet skulle få ha sina rutiner, eller att barnet åt dåligt i övrigt.

Bröstets sexuella konnotationer lyfts också fram som en orsak till att amningen blir mer opassande när barnet blir äldre. Lisa svarar nedan på frågan om vad det är som gör att amning av äldre barn är så speciellt.

Allteftersom det här barnet blir äldre så tycker man att det inte hör till deras värld och att liksom de här brösten börjar kanske liksom ha en mer såhär sexuell betydelse också (Lisa IF mgt 2013/012)

Detta i kombination med att barnet inte längre var "en grönsak" (Ines IF mgt 2017/074), utan en individ som talar och går och kan 
knäppa upp knappar i skjortan gjorde att amningen ändrade karaktär. Detta kan tänkas handla om det beroendeförhållande som det lilla spädbarnet befinner sig i. Spädbarnet ses inte nödvändigtvis som en egen individ, utan som en del av mamman. Ines talade om denna erfarenhet och hur barnet gradvis gick från att ingå $i$ henne själv till att bli en egen individ. Då barnet ses som en del av mamman handlar det inte heller om två kroppar som är nära och intima, något som ses på som mycket privat.

Att amning, i synnerhet offentlig amning, var något som hörde bebistiden till var en norm som starkt framkom i både intervjuerna och kommentarerna. Bland kommentarerna togs det som en självklarhet att amningstiden ändå var så kort, under ett år, och att det därför inte var något problem för kvinnor att hålla sig hemma under den perioden. Att all amning inte var lika framkom mycket tydligt. Den amning som diskuterades antogs handla om en mamma som ammar ett spädbarn, och åsikterna skilde sig mest kring vad som var att vara tillräckligt diskret. Underförstått i kommentarsfältet var att ammande mammor ska vara diskreta oberoende av om åsikten var att hon skulle få amma offentligt eller inte.

Att andra ammade mycket äldre barn var också en situation där informanterna kunde beskriva sig själva som obekväma, även om de annars inte upplevde det obekvämt när andra ammade. Informanterna beskrev också situationer när någon annan ammat ett äldre barn där de gjorde en poäng av att det inte varit obekvämt. Informanterna kunde också uttrycka beundran för de kvinnor som valde att gå emot normen och amma längre än vanligt eller amma mycket öppet utan att dölja sig. Det var situationer de ansåg som mycket obekväma, och som något som kräver mod för att genomföra.

\section{Att orientera sig: problem och strategier}

Jag har i den här artikeln utgått från det informanterna uppgett som att de känner sig obekväma. Jag har strävat efter att se vilka andra känslor som kopplas samman med känslan av obekvämhet och 
visat på vad dessa känslor gör. Genom att undersöka känslorna har jag fått en förståelse för vilka problem som informanterna upplever och vilka strategier som aktiveras då den ammande kroppen rör sig i offentligheten.

Jag har i denna analys utgått från Sara Ahmeds syn på emotioner som rörelse. Känslorna gör något, de flyttar kroppar närmare eller bort från varandra och hänger ihop med hur kroppar tar plats i rummet (Ahmed 2004b:11). Känslorna innefattar också en riktadhet mot något (Ahmed 2004b:8). Att vara obekväm kan i Sara Ahmeds termer också beskrivas som att vara desorienterad. Att vara orienterad är att känna sig hemma, att rummet är en förlängning av den egna kroppen (Ahmed 2006:11).

Man kan konstatera att den ammande kroppen inte känner sig hemma på alla ställen i offentligheten. Kvinnorna i mina intervjuer anpassar sitt rörelsemönster tillsammans med barnet för att undvika ställen där de känner sig som mer obekväma, de strävar till att orientera sig. Det handlar inte bara om att platser inte är (lika) tillgängliga som varit det tidigare, utan om att andra platser nu känns bekväma, som familjecaféer och andra babyaktiviteter, rådgivningens väntrum eller skötrum och amningsrum.

Kvinnorna gick fortsättningsvis på restaurang och åkte kollektivtrafik och de ammade också på dessa platser även om de upplevde det som obekvämt. Där använde de sig dock av strategier för att göra kroppen mer lämplig för utrymmet. Dessa strategier kunde handla om att vända sig bort från andra, sätta sig i hörn eller använda sig av speciella kläder eller sjalar som hindrade insyn. Ofta använde de flera av dessa samtidigt.

Att rummet kunde förvandlas beroende på vilka kroppar som var närvarande syntes extra tydligt då det kom till informanternas egna hem, en plats som de i vanliga fall kände sig bekväma att amma på och inte kände att de behövde använda sig av särskilda strategier på. Vissa kroppar kunde dock göra så att de kände sig obekväma att amma i sitt eget hem och de kunde välja att gå till ett annat rum. Andra människor hade större betydelse än huruvida platsen 
i övrigt var privat eller offentlig för om informanter upplevde amningen som offentlig.

Känslor som förknippades med obekvämhet var känslor som rädsla, pinsamhet, äckel och smärta. Dessa känslor var inte alltid informanternas egna, utan kunde också vara känslor de föreställde sig hos andra. De visade en hög medvetenhet om vad andra människor kunde tänkas känna i de situationer då de ammade, och ville helst inte heller göra andra människor obekväma. Dessa känslor gjorde något med den ammande kroppen och hade effekter på hur informanterna rörde sig i rummet. De var diskreta, något som innebar att de tog mindre plats och gjorde sig mer osynliga. De var kanske inte lika delaktiga i det sociala sammanhanget och kunde välja att gå till ett annat rum för att amma.

Problem kunde uppstå i flera situationer och hängde ofta ihop med andra människor och deras känslor. Problem hänger också ihop med en rädsla för att uppfattas som sexuell, då de var tvungna att blotta en del av kroppen som i övriga fall sågs på som sexuell. De upplevda problemen kunde även handla om att amningen inte följde normer eller att kroppen, eller bröstmjölken, inte gick att kontrollera med läckande bröst som följd.

Känslor hänger ihop med maktstrukturer och formar världen. I sammanhanget offentlig amning har känslorna konkreta effekter på hur kvinnorna rör sig i rummet och vilka platser som blir tillgängliga. Känslan av att vara obekväm varierar över tid och rum och är beroende av föreställningar om kvinnlighet, moderskap, barns individualitet och bröstets sexuella konnotationer. Känslan av att vara obekväm hindrar inte kvinnorna från att amma offentligt, men den gör att konkreta strategier behövs för att göra amningen lämplig för det offentliga rummet och upplevelsen av att amma inte ska kännas för svår. 


\section{Referenser}

\section{Arkivmaterial}

Åbo, Åbo Akademi, Kulturvetenskapliga arkivet Cultura

IF mgt 2013/012 (Lisa).

IF mgt 2017/072 (Anna).

IF mgt 2017/073 (Kajsa).

IF mgt 2017/074 (Ines).

IF mgt 2017/075 (Julia).

\section{Elektroniska källor}

Häggman, Fredrik 2017. Amningsrum på Åborestaurang väcker starka känslor på sociala medier. Svenska Yle. Publicerad 26.7.2017. (Hämtad $18.82017)$

Restaurang Aunes Facebooksida. Inlägg om amningsrum. https://www. facebook.com/ravintolaaune.fi/posts/1573790319340553\# (Hämtad 04.09.2019)

Svenska Yles kommentarsfält. https://svenska.yle.fi/artikel/2017/07/26/ amningsrum-pa-aborestaurang-vacker-starka-kanslor-pa-socialamedier (Hämtad 04.09.2019)

\section{Litteratur}

Acker, Michele 2009. Breast is Best... But Not Everywhere: Ambivalent Sexism and Attitudes Toward Private and Public Breastfeeding. Sex Roles 2009, 61. 476-490.

Ahmed, Sara 2004a. Collective feelings: or, the impressions left by others. Theory, Culture \& Society, 21:2. 25-42.

Ahmed, Sara 2004b. The cultural politics of emotion. Edinburgh University Press, Edinburgh.

Ahmed, Sara 2006. Queer phenomenology: orientations, objects, others. Duke University Press, Durham, N.C.

Ahmed, Sara 2010. Vithetens fenomenologi. Tidskrift för genusvetenskap 1-2 2012. 49-69. 
Barad, Karen 1996. Getting real: technoscientific practices and the materialization of reality. differences. A Journal of Feminist Cultural Studies 10:2. 87-128.

Boyer, Kate 2016. The emotional resonances of breastfeeding in public: The role of strangers in the breastfeeding practice. Emotion, Space and Society 26 (2018). 33-40.

Boyer, Kate 2018. Breastmilk as agentic matter and the distributed agencies of infant feeding. Studies in the Maternal 10(1):11. 1-23.

Bränström Öhman, Annelie; Jönsson Maria \& Svensson, Ingeborg 2011. Inledning. I: Att känna sig fram: Känslor i humanistisk genusforskning. Red. Bränström Öhman, Annelie; Jönsson Maria \& Svensson, Ingeborg. H:ström, Umeå. 7-19.

Callaghan, Jane E.M. \& Lazard, Lisa 2012. 'Please don't put the whole dang thing out there!': A discursive analysis of internet discussions around infant feeding. Psychology and Health 27:8. 938-955.

Callen, Jennifer \& Pinelli, Janet 2004. Incidence and Duration of Breastfeeding for Term Infants in Canada, United States, Europe, and Australia: A Literature Review. Birth 31:4. 285-292.

Dahl, Lena 2004. Amningspraktikens villkor. En intervjustudie av en grupp kvinnors föreställningar om förväntningar på och erfarenheter av amning. Diss. Göteborgs universitet, Göteborg.

Douglas, Mary 1997. Renhet och fara: en analys av begreppen orenande och tabu. Nya Doxa, Nora.

Ehn \& Löfgren 2001. Kulturanalyser. Gleerup, Malmö.

Grosz, Elizabeth 1994. Volatile bodies: toward a corporeal feminism. Indiana University Press, Bloomington.

Hamréus, Anna \& Ivanoff, Julia 2010. Mödrars attityder till långtidsamning. Magisteruppsats, Göteborgs universitet.

Henriksson, Blanka 2007. "Var trogen i allt". Den goda kvinnan som konstruktion i svenska och finlandssvenska minnesböcker 1800-1980. Åbo Akademis förlag, Åbo.

Johnston-Robledo, Ingrid; Stephanie Wares, Jessica Fricker \& Leigh Pasek 2007. Indecent Exposure: Self-objectification and Young Women's Attitudes Toward Breastfeeding. Sex Roles (2007) 56. 429-437. 
Laanterä, Sari; Tarja Pölkki, Anette Ekström \& Anna-Maija Pietilä 2010. Breastfeeding attitudes of Finnish parents during pregnancy. BMC Pregnancy and Childbirth 2010, 10:79. 1-8.

Lane, Rebecca 2014. Healthy discretion? Breastfeeding and the mutual maintenance of motherhood and public space. Gender, Place \& Culture, 21:2. 195-210.

Longhurst, Robyn 2001. Bodies: exploring fluid boundaries. Routledge, London.

Longhurst, Robyn 2008. Maternities: gender, bodies and space. Routledge, New York.

Metsämäki, Lina 2018. "Man känner sig kanske ännu mer som en kvinna efter att man har fått amma två barn": makt, materialitet och performativ kvinnlighet $i$ intervjuer om offentlig amning. Avhandling pro gradu, Åbo Akademi.

Murphy, Elizabeth 1999. 'Breast is best': infant feeding decisions and maternal deviance. Sociology of health and illness. 21:2. 187-208.

Nilsson, Fredrik \& Marander-Eklund, Lena 2018. Under ytan.

Kulturanalyser av det bortglömda, dolda och triviala. Budkavlen 2018: Under ytan. 1-10.

Owens, Nicole; Shannon K. Carter; Chelsea J. Nordham \& Jason A. Ford 2016. Neutralizing the maternal breast. Accounts of public breastfeeding by African American mothers. Journal of Family Issues. 39:2. 430-450.

Shouse, Eric 2005. Feeling, emotion, affect. M/C Journal 8/6 2005. Hämtad 6.52019 på http://journal.media-culture.org.au/0512/03shouse.php

Stearns, Cindy 1999. The good maternal body. Gender and Society 13:3. 308-325.

Svensson 2011. Liv plats och identitet i det urbana rummet. I: Andra Stockholm: liv, plats och identitet $i$ storstaden. Red. Larsson, Bo \& Svensson, Birgitta. Stockholmia, Stockholm. 21-32.

Tuan, Yu-Fi 1979. Space and place: humanistic perspective. I: Philosophy in geography. Red. Gale, Stephen \& Olsson, Gunnar. Dordrecht. 387-427.

Uusitalo, Liisa; Heidi Nyberg, Marjaana Pelkonen, Sirpa SarlioLähteenkorva, Tuovi Hakulinen-Viitanen, Suvi Virtanen 2012. 
Imeväisikäisten ruokinta Suomessa vuonna 2010. Terveyden ja hyvinvoinnin laitos, Helsinki.

Wennstam, Katarina 2002. Flickan och skulden. En bok om samhällets syn på våldtäkt. Bonnier, Stockholm.

Yalom, Marilyn 1997. A history of the breast. Knopf, New York.

Young, Iris Marion 1998. Breasted Experience. I: The politics of women's bodies: Sexuality, appearance and behavior. Red. Weitz, Rose. Oxford University Press, New York. 125-136.

\section{Noter}

1 Intervjuerna är arkiverade vid Kulturvetenskapliga arkivet Cultura vid Åbo Akademi.

2 Folkhälsans familjecafé är en gratis samlingsplats för föräldrar och barn som besöks av främst föräldralediga mammor och pappor tillsammans med sina barn. Det organiseras en gång i veckan.

3 Ett amningsvårtskydd, även kallat amningsnapp, är ett hjälpmedel vid amning som består av ett tunt silikonmaterial som läggs på bröstvårtan vid amning för att lindra smärtan. 


\section{To Feel Uncomfortable but Still Breastfeed Problematic feelings and bodies in narratives about public breastfeeding}

\section{Lina Metsämäki}

This article focuses on problems and strategies that are activated when a breastfeeding individual is engaging in activities in public spaces. The aim was to examine through the engendered feelings of being uncomfortable which problems a person encounters and what these feelings do to their body. This was done through a close reading of five interviews about breastfeeding in public and comments on an article about public breastfeeding published on the webpages of Svenska Yle during the summer of 2017.

Feelings of being uncomfortable did not stop the informants from breastfeeding in public, but the feelings made their bodies engage with the space in a different manner. The informants regulated their bodies through their feelings of being uncomfortable. They used strategies to make their breastfeeding as invisible as possible, such as turning away from public attention or using certain clothes or scarves to conceal they are nursing or going into another room to breastfeed. Feelings like fear, disgust, embarrassment, shame and pain are all connected to the feeling of being uncomfortable.

The problems are also connected to the sexual connotations of the female breast and it was important for the informants not to come across as being sexual while breastfeeding. Since the breast is usually considered sexual and men are assumed to be sexually attracted to female breasts problems arise. Other problems concern the fact that other people may be made to feel uncomfortable or being pointed out and receiving negative comments while breastfeeding. Bodily functions can be problematic as well, especially leaking breastmilk that may leave stains on clothing. Another problem was breaking the norms surrounding breastfeeding, for instance by breastfeeding an older child. 